\title{
PERAN PUBLIC RELATIONS DALAM MENINGKATKAN CITRA HOTEL SAHID MELALUI EVENT YOGA
}

\author{
Asti Haningtyas \\ STIKOM London School of Public Relations \\ Email: contact@astihaningtyas.com
}

Diterima : 30 Juli 2018

Disetujui : 15 Agustus 2018

Diterbitkan : 31 Agustus 2018

\begin{abstract}
Abstrak
Perkembangan industri hotel saat ini semakin marak, Hotel Grand Sahid Jaya - Jakarta yang sudah berdiri semenjak tahun 1974 ini semakin ketat persaingannya dengan kehadiran hotelhotel baru yang menawarkan tema lebih variatif dan harga yang lebih terjangkau, citra Hotel Grand Sahid Jaya - Jakarta sudah semakin menurun dan public relations memiliki peran penting dalam membangun, mempertahankan dan meningkatkan citra dari hotel ini. Penelitian ini dilakukan untuk mengetahui peran public relations dalam meningkatkan citra Hotel Grand Sahid Jaya - Jakarta melalui kegiatan event Sunrise Yoga from The Skyline, penelitian ini menggunakan metode kualitatif sebagai metodologi penelitian, studi ini juga menggunakan teori peran public relations oleh Ruslan. Hasil penelitian menunjukan bahwa public relations memiliki peran penting dan sudah menjalani perannya sesuai dengan teori yang digunakan untuk meningkatkan citra Hotel Grand Sahid Jaya - Jakarta.
\end{abstract}

Kata Kunci: Peran public relations, citra, hotel

\begin{abstract}
Hotel industry is currently booming and Grand Sahid Jaya Hotel - Jakarta, which has been established since 1974, is facing tough competition with the arrival of hotels offering a variety of themes and more affordable prices. The image of Grand Sahid Jaya Hotel Jakarta has been declining and public relations plays an important role in rebuilding, maintaining, and improving the hotel's image. This research was done to understand the role of public relations in improving the image of Grand Sahid Jaya Hotel - Jakarta through the Sunrise Yoga from the Skyline event using qualitative data for the research method. This study also uses the role of public relations elements by Ruslan. The research results shows that public relation plays an important role and has fulfilled its theoretical role that was used to improve the image of Grand Sahid Jaya - Jakarta.
\end{abstract}

Keywords: Role of public relations, image, hotel

\section{PENDAHULUAN}

Perkembangan dunia perhotelan di Indonesia semakin merambah, munculnya hotelhotel baru yang kini menawarkan fasilitas lengkap dengan harga yang sangat terjangkau sudah hadir dengan berbagai versi dan tema unik yang masing-masing ditawarkan oleh pihak hotel, di satu sisi hotel-hotel yang sudah lebih dulu menguasai pasar terlebih di kota pusat bisnis, yaitu DKI Jakarta harus bersiap-siap dalam menghadapi kemunculan hotel-hotel low budget siap merebut pasar yang sudah mereka kuasai terlebih dahulu, diantaranya adalah Hotel Grand Sahid Jaya - Jakarta. 
Menurut riset Konsultan Properti Cushman \& Wakefield menunjukan, tingkat hunian hotel bintang tiga, empat dan lima Di Indonesia menurun masing-masing 57,4\%, 61,0\% dan 55,7\% di akhir 2015. Namun tidak menutup kemungkinan apabila di akhir tahun 2016, perekonomian menurun dan Cushman \& Wakefield memperkirakan kebutuhan kamar hotel di Indonesia menjadi 56,6\%, 57,1\% dan 55,3\% di akhir 2016 (Herawan, 2016, April 21).

Hotel Grand Sahid Jaya - Jakarta adalah salah satu hotel bintang lima di Jakarta dengan jaringan grup terbesar di Indonesia yang sudah lama berdiri semenjak 23 Maret 1974. Hotel Grand Sahid Jaya - Jakarta didirikan oleh Sukamdani Sahid Gitosarjono, hotel ini dibangun dengan nuansa tradisional Indonesia yang dikombinasikan dengan profesionalitas dari industri perhotelan, sampai saat ini Hotel Grand Sahid Jaya - Jakarta tetap mempertahankan nuansa budaya dan identitas lokal dalam setiap desain dan tata letak ruangnya (Grand Sahid Jaya, 2016, 18 Februari).

Perkembangan hotel masa kini, tidak hanya berhenti dalam menawarkan terbaik saja namun juga memberikan pengalaman berbeda yang dapat menjadikan para konsumen untuk tertarik dalam menginap di hotel tersebut. Hiasan dinding, aksesoris, kafe ataupun restoran dengan sajian makanan yang cantik dan menarik untuk diabadikan di media social dapat menjadi salah satu faktor mengapa banyak konsumen belia yang senang mengunjungi hotelhotel dengan tema yang unik, meskipun nyatanya mereka tidak menginap di hotel tersebut.

Semenjak tahun 2015, berdasarkan riset dari Sun Life Financial bersama Ipsos Indonesia, empat dari lima orang merasa bahwa diri mereka sehat. Meningkatnya indeks kesadaran masyarakat Indonesia tentang kesehatan sebesar 73\% bahwa kesehatan adalah isu nomor satu dalam prioritas hidup mereka masing masing, angka ini meningkat sebesar 19\% dari tahun kemarin (Pernando, 2015, November 13).

Generasi tidak punya satu definisi pasti karena sebetulnya tokoh yang mempelajari generasi tidak hanya dua. Strauss dan Howe mendefinisikan generasi sebagai agregat dari semua orang yang lahir selama rentang waktu sekitar dua puluh tahun atau sekitar panjang satu fase dari masa kanak-kanak, dewasa muda, usia pertengahan dan usia tua. Selain itu terdapat tiga kriteria yang harus dimiliki oleh sebuah generasi yaitu usia lokasi dalam sejarah, kepercayaan dan perilaku yang sama, serta keanggotaan periode yang sama. Kriteria pertama maksudnya adalah generasi yang sama akan mengalami peristiwa sejarah penting dan tren sosial bersamaan (Rey, 2017, Oktober 21).

Generasi $\mathrm{O}$ adalah mayoritas penduduk Indonesia yang berumur 25 - 55 tahun, dengan beban kerja yang sangat besar, O berasal dari generasi yang overworked (terlalu banyak bekerja), overweight (kelebihan berat badan), overwhelmed (kelelahan). Saat ini Generasi O merupakan generasi yang menjadi perhatian public setelah Generasi Y. Generasi inilah yang sudah memiliki kesadaran bahwa penyakit berbahaya sudah mengintai tubuh mereka apabila mereka belum berencana untuk mengubah gaya hidup mereka dalam waktu dekat (Perempuan.com, 2014, Oktober 23).

Ada banyak sekali pilihan olahraga bagi Generasi O untuk dapat meringankan ancaman penyakit bahaya dari tubuh mereka, sayangnya mereka tidak punya waktu cukup banyak untuk melakukan morning jogging ataupun bergabung di fitness club seperti Celebrity Fitness, Gold Gym atau Fitness First. Komunitas pecinta olahraga semakin bermunculan dengan jadwal latihan yang fleksibel dan tidak memungut biaya besar.

Yoga sudah mulai dikenal sebagai salah satu olahraga ringan yang aman dan nyaman untuk dilakukan setiap minggu, atau bahkan untuk mencapai hasil terbaik mereka bisa melakukannya setiap hari tanpa memakan waktu yang lama. Kesadaran akan sehat yang sudah mulai meningkat membuat Hotel Grand Sahid Jaya - Jakarta berinovasi dalam mengeluarkan event Sunrise Yoga from The Skyline, kegiatan yoga yang dilaksanakan di Helipad Hotel Grand Sahid Jaya - Jakarta, Lantai 22. Acara ini sudah berlangsung selama 5x 
semenjak bulan Mei 2016, berbagai macam peserta dari berbagai segmentasi berkumpul di Helipad Hotel Grand Sahid Jaya - Jakarta. Yoga yang dipraktikan di acara ini adalah jenis hatha yoga yang mana adalah yoga dengan gerakan basic yang mendasar, yoga ini melatih teknis pernapasan dan pose yang meregangkan otot-otot di tubuh.(Yuanita Ayu Pratama, wawancara data primer, 11 April 2017)

Tak sedikit, para keluarga yang ikut berpartisipasi mereka juga membawa anakanaknya untuk bergabung di acara Sunrise Yoga from The Skyline, mereka menghabiskan minggu pagi mereka dengan melakukan olahraga bersama keluarga dan anak-anak mereka, tentunya berbeda apabila melakukan yoga dari gedung pencakar langit, kualitas udara yang didapatkan pun berbeda.

Citra Hotel Grand Sahid Jaya - Jakarta yang sudah dikenal lama sebagai hotel lama tentunya menjadi hambatan bagi manajemen untuk bisa menyentuh berbagai kalangan segmentasi masyarakat, apalagi saat ini golongan muda lah yang produktif dalam melakukan kegiatan dan bisa kapan saja bersentuhan atau membutuhkan jasa hospitality. Kegiatan yoga yang dikenal sebagai salah satu program kekinian ini, diharapkan dapat menyentuh lebih banyak golongan, merangkul dan memperkenalkan kembali Hotel Grand Sahid Jaya Jakarta sebagai hotel yang up to date dan tetap memperhatikan tren masa kini.

Tujuan dari kegiatan ini adalah dapat meningkatkan kembali citra dari Hotel Grand Sahid Jaya, proses komunikasi kepada masyarakat melalui publikasi yang ada diharapkan agar masyarakat mengetahui kegiatan ini dan semakin banyak masyarakat dari berbagai macam umur yang berpartisipasi dalam acara ini, tentunya dapat meningkatkan citra dari Hotel Grand Sahid Jaya yang sudah cukup berumur.

Awal mula terbentuknya konsep ini tak lain juga karena adanya fasilitas helipad yang jarang digunakan sehingga terbersit ide dari divisi Public Relations untuk menggunakan tempat tersebut sebagai venue dari Sunrise Yoga from The Skyline dari Hotel Grand Sahid Jaya - Jakarta (Yuanita Ayu Pratama, wawancara data primer, 11 April 2017).

Menurut Harlow dikutip dari bukunya "Building a Public Relations Definition," Public Relations adalah fungsi manajemen tertentu yang membantu membangun dan menjaga lini komunikasi, pemahaman bersama, penerimaan mutual dan kerja sama antara organisasi dan publiknya; PR melibatkan manajemen problem atau manajemen isu; PR membantu manajemen agar tetap responsif dan mendapat informasi terkini tentang opini publik; PR mendefinisikan dan menekankan tanggung jawab manajemen untuk melayani kepentingan publik; PR membantu manajemen tetap mengikuti perubahan dan memanfaatkan perubahan secara afektif, dan PR dalam hal ini adalah sebagai sistem peringatan dini untuk mengantisipasi arah perubahan (trends); dan PR menggunakan riset dan komunikasi yang sehat dan etis sebagai alat utamanya (Cutlip, 2006, p.5)

Adanya keinginan dari setiap organisasi, komunitas maupun perusahaan untuk memiliki citra yang baik dan positif di hadapan masyarakat, muncul berbagai macam definisi dari dari para ahli mengenai citra yakni buku karangan Soemirat dan Ardianto, mereka mengutip definisi Citra yang dikemukakan oleh Bill Canton yang berbunyi :

"Image: the impression, the feeling, the conception which the public has of a company; a consciously created impression of an object, person or organization" yang berarti citra adalah kesan, perasaan, gambaran diri publik terhadap perusahaan ; kesan yang dengan sengaja diciptakan dari suatu obyek, orang atau organisasi” (Soemirat, 2012, p.111).

Menurut Dewney, mengatakan bahwa "citra perusahaan merupakan impresi mengenai perusahaan yang ada dalam benak konsumen". Frank Jefkins menyatakan bahwa citra adalah "kesan seseorang atau individu tentang sesuatu yang muncul sebagai hasil dari pengetahuan dan pengalamannya" (Soemirat, 2012, p.114). 
Mengutip dari Jefkins, dalam Public Relations (1984) dan buku lainnya Essential of Public Relations (1998) oleh Soemirat dan Ardianto pada buku "Dasar-Dasar Public Relations" mengemukakan jenis citra diantaranya : (1) The Mirror Image (cerminan citra), bagaimana dugaan (citra) manajemen terhadap publik eksternal dalam melihat perusahaannya. (2) The Currently Image (citra masih hangat), yaitu citra yang terdapat pada publik ekternal, yang berdasarkan pengalaman atau menyangkut miskinnya informasi dan pemahaman publik eksternal. Citra ini bisa saja bertentangan dengan miror image. (3)The Wish Image (citra yang diinginkan), yaitu manajemen menginginkan pencapaian prestasi tertentu. Citra ini diaplikasikan untuk sesuatu yang baru sebelum publik eksternal memperoleh informasi secara lengkap. (4) The Multiple Image (citra yang berlapis), yaitu sejumlah individu, kantor cabang atau perwakilan perusahaan lainnya dapat membentuk citra tertentu yang belum tentu sesuai dengan keseragaman citra seluruh organisasi atau perusahaan (Soemirat, 2012, p.117).

Dalam buku "Dasar - Dasar Public Relations", Soemirat dan Ardianto mengutip proses pembentukan citra berdasarkan definisi Danasaputra Citra terbentuk berdasarkan pengetahuan dan informasi-informasi yang diterima seseorang. Komunikasi tidak secara langsung menimbulkan perilaku tertentu, tetapi cenderung mempengaruhi cara kita mengorganisasikan citra kita kepada lingkungan. Proses pembentukan citra dalam struktur kognitif yang sesuai dengan pengertian sistem komunikasi dijelaskan oleh Nimpoeno, dalam laporan penelitian tentang Tingkah Laku Konsumen, seperti yang dikutip Danasaputra sebagai berikut :

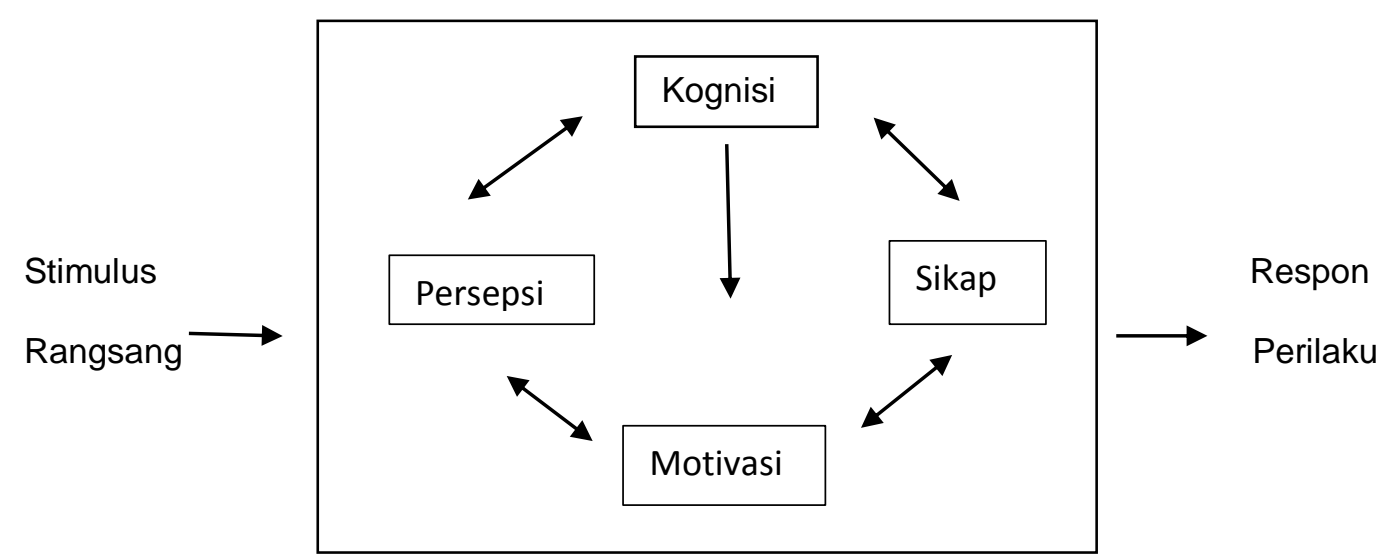

Model Pembentukan Citra, dari Dasar-dasar Public Relations, 2012

Empat komponen persepsi-kognisi-motivasi-sikap diartikan sebagai citra individu terhadap rangsang. Ini disebut sebagai "picture in our head" oleh Lipman.

Persepsi diartikan sebagai hasil pengamatan terhadap unsur lingkungan yang dikaitkan dengan suatu proses pemaknaan. Dengan kata lain, individu akan memberikan makna terhadap rangsang berdasarkan pengalamannya mengenai rangsang. Kemampuan mempersepsi itulah yang dapat melanjutkan proses pembentukan citra. Persepsi atau pandangan individu akan positif apabila informasi yang diberikan oleh rangsang dapat memenuhi kognisi individu

Kognisi yaitu suatu keyakinan diri dari individu terhadap stimulus. Keyakinan ini akan timbul apabila individu telah mengerti rangsang tersebut, sehingga individu harus diberikan informasi-informasi yang cukup yang dapat mempengaruhi perkembangan kognisinya. Motivasi dan sikap yang ada akan menggerakkan respons seperti yang diinginkan oleh pemberi rangsan 
Motif adalah keadaan dalam pribadi seseorang yang mendorong keinginan individu untuk melakukan kegiatan-kegiatan tertentu guna mencapai suatu tujuan Sikap adalah kecenderungan bertindak, berpersepsi, berpikir, dan merasa dalam menghadapi objek, ide, situasi atau nilai (Soemirat, 2012, p.114).

Seorang Public Relations dituntut untuk bisa menjalan banyak fungsinya sebagai PR dengan baik, juga harus menjalankan perannya dengan baik. Bila dilihat sekilas, tak tampak adanya perbedaan yang signifikan diantara fungsi dan peran, namun sebenarnya kedua kata tersebut memiliki pengertian yang berbeda. Fungsi bermaksud pada apa yang harus dilakukan atau melakukan suatu adanya kegiatan, sedangkan peran dimaksud lebih kepada tanggung jawab dari seorang yang memiliki profesi Public Relations.

Peran dari Public Relations dijelaskan intinya sebagai berikut (Ruslan, 2005, p.10) sebagai communicator atau penghubung antara organisasi atau lembaga yang diwakili dengan publiknya, dari adanya penjelasan tersebut dijelaskan bahwa Public Relations berperan sebagai perwakilan perusahaan dalam melakukan komunikasi dengan publik internal dan komunikasi dengan publik internal. Membina Relationship, yakni berupaya selalu untuk membina hubungan yang harmonis dan saling menguntungkan bagi kedua belah pihak. Dalam hal ini Public Relations berperan dalam melakukan pendekatan hubungan baik dengan publik baik internal maupun eksternal yang dapat menjadi kesempatan bagi kedua belah pihak di masa mendatang. Adanya peranan Back Up Management, yaitu sebagai alat pendukung dalam adanya fungsi manajemen organisasi atau suatu perusahaan. Public Relations memiliki peranan yang bertugas sebagai pendukung perusahaan yang selalu siap untuk menjalankan tugas yang diberikan dari perusahaan yakni membentuk Corporate Image, yaitu peranan Public Relations berupaya menciptakan citra bagi perusahaan atau lembaganya yang bersangkutan.

Berdasarkan konsep peran public relations dari Rusdy Ruslan, peran public relations terdiri dari communicator, relationship, back up management dan corporate image. Peran public relations sangatlah penting dalam berlangsungnya suatu event baik itu bersifat internal maupun eksternal dalam membangun dan meningkatkan citra Hotel Grand Sahid Jaya - Jakarta, maka dari itu berdasarkan latar belakang yang sudah disampaikan maka dari itu dibuatlah penelitian "Peran Public Relations Dalam Meningkatkan Citra Hotel Grand Sahid Jaya - Jakarta melalui Event Sunrise Yoga from The Skyline".

\section{METODOLOGI PENELITIAN}

Metode yang digunakan oleh peneliti saat ini adalah melalui pendekatan kualitatif. Dalam penelitian sosial, masalah penelitian, tema dan topik baik secara substansi dan konten berbeda dengan pendekatan kualitatif dan kuantitatif. Dalam hal ini, yang menjadi asumsi dasar dalam penelitian post-provistik adalah (Ardianto, 2009, p.61); Pengetahuan bersifat konjektual dan tidak berlandaskan apapun. Kita tidak pernah mendapatkan kebenaran yang bersifat absolute. Penelitian merupakan proses membuat klaim-klaim, kemudian menyaring sebagian klaim tersebut menjadi klaim-klaim lain yang kebenarannya jauh lebih kuat. Pengetahuan dibentuk oleh data, bukti dan pertimbangan logis. Dalam praktiknya, peneliti mengumpulkan informasi dengan menggunakan instrumen pengukuran tertentu yang diisi oleh partisipan atau dengan melakukan observasi mendalam. Penelitian harus mampu mengembangkan penyataan yang relevan dan benar, penyataan yang dapat menjelaskan situasi yang sebenarnya atau, mendeskripsikan relasi kausalitas dari suatu persoalan. Aspek terpenting dalam penelitian ini adalah sikap objektif. Para peneliti harus menguji kembali metode dan kesimpulan yang sekiranya mengandung bias.

Dalam hal penelitian saat ini, peneliti menggunakan teknik pemeriksa keterpercayaan yang menggunakan triangulasi sumber, peneliti menggunakan wawancara sebagai teknik 
pengumpulan data dengan mewawancarai sumber yang berbeda. Sumber yang digunakan oleh peneliti yakni adalah pihak internal dari Hotel Grand Sahid Jaya - Jakarta divisi Public Relations, Kepala Dokumentasi Hotel Grand Sahid Jaya - Jakarta, perwakilan peserta Event Sunrise Yoga from The Skyline.

\section{HASIL DAN PEMBAHASAN}

Setiap perusahaan yang menawarkan produk berupa jasa dan barang tentunya memiliki visi dan misi tersendiri agar bergeraknya perusahaan tersebut terarah dan mengacu pada visi dan misi perusahaan itu tersebut, tidak terlepas dari Hotel Grand Sahid Jaya Jakarta yang juga memiliki ketertarikan dan loyalitas dalam melayani tamunya juga memiliki visi dan misi tersendiri yang tak telak ditelan zaman.

Visi dari Grand Sahid Jaya menjadi hotel yang mampu menumbuhkan kreativitas, inovasi, produktivitas, kualitas sumber daya manusia yang teruji dan menyajikan pelayanan yang sesuai dengan standard internasional yang tanpa meninggalkan nilai nilai keluhuran budaya nusa bangsa.

Misi hotel ini diantaranya adalah meningkatkan kualitas produk dan mutu pelayanan dengan sasaran dan juga memberikan kepuasan kepada pelanggan. Meningkatkan kualitas sumber daya manusia agar menjadi terampil dan memiliki kemampuan untuk memberikan pelayanan yang terbaik guna memuaskan pelanggan dengan cara professional dan proaktif dalam menghadapi perubahan tuntutan masyarakat yang semakin canggih dan lingkungan yang juga semakin kompetitif. Mempercepat pengembangan perseroan menjadi perusahaan professional, produktif dan efisien yang unggul dalam nasional suasana persaingan yang semakin meningkat. Meningkatkan upaya pengembangan usaha baik dibidang bisnis utama (primary core business) maupun bisnis sekunder (secondary core business) sehingga mampu memantapkan keunggulan posisinya dalam kegiatan perekonomian Indonesia pada khususnya. Menggali sumber pendanaan yang lebih inovatif dan menguntungkan perusahaan untuk membiayai pembangunan dan pengembangan usaha melalui pasar modal, lembaga keuangan nasional maupun internasional serta menjalin kerjasama dengan pihak lain dalam upaya meningkatkan efisiensi dan produktivitas perusahaan.

Dewasa ini banyak sekali program olahraga kesehatan yang dikonsep dengan gaya apik, stylish dan bisa mencakup berbagai umur. Produktivitas yang tinggi membuat para individu cenderung melupakan pentingnya memiliki gaya hidup sehat ditengah penuhnya keseharian. Yoga merupakan salah satu cara olah tubuh yang cukup trending di kalangan anak muda, olah tubuh ini dipercaya dapat meringankan pernafasan dan meningkatkan elastisitas tubuh. Program olah tubuh banyak ditawarkan dari komunitas yang peduli dengan kesehatan, studio, fitness center hingga hotel terkemuka yang sudah memiliki kesadaran tentang pentingnya olah tubuh, tak lepas dari tren masa kini yang menjadi kunci program Sunrise Yoga from The Skyline oleh Hotel Grand Sahid Jaya - Jakarta.

Hotel Grand Sahid Jaya merupakan besutan dari PT Hotel Sahid Jaya Internasional Tbk, yang berdiri pada tanggal 23 Mei 1969 yang ditujukan untuk membangun usaha perindustrian hotel dan pariwisata. Pada awalnya tahun 1974, perusahaan tersebut membangun suatu hotel di daerah Jalan Jenderal Sudirman 86 di Jakarta yang kemudian dioperasikan pada tanggal 23 Maret tahun 1974, bangunan hotel tersebut dinamakan Hotel Sahid Jaya. Hotel Sahid Jaya saat itu memiliki 439 kamar, hotel tersebut juga memiliki beberapa ruangan pertemuan yang dapat digunakan untuk berbagai kegiatan, disamping itu juga ada restoran dan fasilitas olahraga seperti kolam renang.

22 Desember 1986 para pemegang saham perusahaan mulai membangun pengembangan dari bangunan hotel lama yang sudah dibangun, adanya peningkatan jumlah kamar yang sampai saat itu berjumlah 752 kamar kemudian membuat para pemegang saham 
memutuskan untuk mengajukan suatu Penawaran Umum Perdana dan mencatatkan saham di Bursa Efek Jakarta. Perusahaan tersebut pada tanggal 22 Desember 2011 telah mengadakan rapat organisasi yang kemudian sudah disetujui pada saat Rapat Umum Pemegang Saham Luar Biasa pada hari dan tanggal yang sama. Hotel ini pada tanggal 23 Mei 2009 yang juga bertepatan dengan hari ulang tahunnya yang ke 35 kemudian mengubah namanya, Hotel Sahid Jaya sudah bertransformasi menjadi Hotel Grand Sahid Jaya pada saat ini, Hotel Grand Sahid Jaya saat ini menggunakan banyak jenis media mulai dari media cetak dan media elektronik. Media cetak yang digunakan antaranya adalah pamflet, spanduk, poster, papan pengumuman, majalah dan media konvensional lainnya. Media elektronik yang digunakan adalah Youtube, Facebook, Twitter, Website dan Survey Online.

- Lingkaran Emas

Lingkaran berwarna emas adalah melambangkan bumi tempat berpijak dimana Group Sahid mendapat peluang untuk bisa mengoperasikan kelompok usahanya dalam bekerjasama antara pemilik, pengelola dan karyawan pemerintah, pengguna jasa, mitra usaha, penyandang dana, masyarakat dan lingkungannya. Cita-cita Sahid Internasional Hotel Management and Consultant (SIHMC) untuk mengupayakan peluang tersebut sebagai sumber dan kegiatan ekonomi baik secara internasional maupun nasional.

- Huruf "S" Warna Merah

Singkatan dari nama Sahid yang bernamakan historis, filosofis, ekonomis, politis, yang melambangkan cita cita pendirinya sebagai pengayom dan pelindung bagi keluarga besar Sahid Jaya. Adanya pedoman Tri Watak Budi Luhur yakni taat kepada Tuhan YME, berbakti kepada orang tua, bangsa dan Negara juga menciptakan keseimbangan antara cinta kepada profesi dan keluarga.

- Caka di Ujung Huruf S

Mencapai semua itu oleh pendiri Grand Sahid Jaya dilambangkan dengan cakra yang memiliki empat mata penjuru, yakni melambangkan cita-cita agar Sahid berputar terus menerus dan saling mengisi sepanjang masa depan mengandalkan kekuatan kakuatan musuh diatas, bawah samping kiri, dan kanan. Bisa diibaratkan senjata cakra ini mengandung makna luhur "Jaya satu, Jaya semua, terganggu satu saling membantu agar tetap berjaya."

Seluruh media yang digunakan oleh Hotel Grand Sahid Jaya bertujuan untuk menginformasikan pemberitahuan kepada masyarakat perihal program terbaru, harga kamar dan penawaran menarik lainnya oleh Hotel Grand Sahid Jaya. Pada media elektronik yakni Facebook, Hotel Grand Sahid Jaya mempublikasikan hasil kegiatan yang dilaksanakan di Hotel Grand Sahid Jaya Jakarta seperti konferensi, pernikahan, syukuran, pengajian, hari ulang tahun dan lain lain.

Sunrise Yoga from The Skyline merupakan besutan dari Public Relations Division Hotel Grand Sahid Jaya - Jakarta, setelah melalui berbagai macam pertemuan oleh direksi hotel, department head dan diskusi secara internal maka lahirlah kegiatan Yoga ini yang dilaksanakan di Helipad Hotel Grand Sahid Jaya Lt. 21.

Diawali dengan kepedulian mengenai kesehatan yang sekarang sedang cukup banyak menjadi bahan obrolan dan sedang trending, event ini dibuat untuk para pemerhati kesehatan yang sudah terlalu lama hidup dengan junk food dan pola hidup yang tidak baik, mayoritas dari pelanggan Hotel Grand Sahid Jaya yang berumur setengah baya keatas membuat para manajemen hotel ingin meningkatkan citranya lagi agar dapat bersaing dengan hotel lain yang memiliki berbagai macam segmentasi tamu termasuk remaja dan anak muda.

Dalam cara menganalisis hasil penelitian, peneliti saat ini mengacu pada teori peran Public Relations yang ditulis oleh Roesdy Ruslan di buku Manajemen Public Relations dan Media Komunikasi : Konsepsi dan Aplikasi (2005, p.10) yakni sebagai berikut : 


\section{Menjadi Communicator}

Divisi Public Relations berperan sebagai penghubung antara organisasi atau lembaga yang diwakili dengan publiknya. (Ruslan, 2005, p.10 "Kita menjalin komunikasi antara publik dan hotel, ada banyak sekali tools yang kita gunakan dalam menjalin komunikasi antara hotel dan publik seperti melakukan aktivitas yang bersifat melibatkan masyarakat sekitar seperti fun walk, donor darah dan acara cooking class. " (Yuanita Ayu Pratama, wawancara data primer, 11 April 2017)

Pada pernyataan ini, sesuai dengan peran public relations sebagai communicator, dimana divisi public relations sudah menjalankan tugasnya sebagai seorang communicator yakni penghubung antara pihak hotel dan publik dan juga menyediakan berbagai macam media komunikasi untuk memudahkan publik menjangkau informasi dari Hotel Grand Sahid Jaya - Jakarta. Hal ini juga dikuatkan dengan pernyataan narasumber pertama dalam penjelasannya : "Bila berkomunikasi kepada eksternal kita memiliki media sosial yakni facebook, youtube, twitter, instagram dan website yang setiap hari selama 24 jam bisa diakses dan digunakan oleh seluruh visitor. Kita juga menjawab direct messages yang masuk ke media sosial kita." (Yuanita Ayu Pratama, wawancara data primer, 11 April 2017)Pernyataan diatas menjelaskan bahwa, divisi public relations sudah menggunakan berbagai macam alat komunikasi untuk mempermudah publik yang ingin menggali informasi mengenai Hotel Grand Sahid Jaya - Jakarta. Divisi public relations juga membuka kesempatan seluas - luasnya untuk berkomunikasi secara dua arah lewat media sosial.

Dalam menjalankan perannya sebagai divisi public relations, tidak luput dari menjalankan tugasnya untuk menjadi communicator di kalangan internal yakni antar karyawan. "Dalam berkomunikasi antar internal di perusahaan, kita menggunakan banyak media di antaranya majalah dinding di lorong karyawan yang digunakan untuk menampilkan karyawan yang berulang tahun setiap bulannya. Sebagai publikasi kegiatan internal yang diadakan setiap bulan dan juga, menampilkan foto best employees setiap tahun, ada juga email internal yang digunakan untuk memberitahukan kegiatan yang diselenggarakan di hotel, biasanya bertujuan sebagai announcement kepada seluruh departemen." (Yuanita Ayu Pratama, wawancara data primer, 11 April 2017)

\section{Menjaga Relationship}

Berupaya selalu untuk membina hubungan yang harmonis dan saling menguntungkan bagi kedua belah pihak. (Ruslan, 2005, p.10) Tentunya penting bagi divisi public relations untuk selalu menjaga dan membina hubungan baik antar internal maupun eksternal dan membuka kesempatan sebesar-besarnya untuk hal yang menguntungkan bagi kedua belah pihak. "Sebagai bagian dari public relations, dukungan yang sudah dilakukan adalah kita mengoptimalkan seluruh cara komunikasi agar dapat mempermudah publik dalam mengakses media sosial kita, kita juga selalu buat konsep visual hingga lebih instagrammable dan lebih mudah untuk dipahami masyarakat dan ngga bosenin." (Idham Yassin, wawancara data primer, 11 April 2017) Dalam hal komunikasi antar internal sangatlah penting, karena dapat berpengaruh pada hasil kinerja hotel, dimana antar departemen bekerja sama untuk melayani tamu dengan performa terbaik.

Hal ini juga didukung dengan pernyataan narasumber ketiga yang menyatakan :

"Buat meminimalisir miskomunikasi sih yang penting jangan telat ngasih kabar atau info bila butuh kerjasama dengan departemen lain, contohnya kaya butuh speaker itu kontak ke departemen IT, buat bersihin helipad sebelom dipake sama peserta dan digelar yogamat biasanya dibawah tanggung jawab departemen housekeeping, jadi jangan sampe jelek hubungan internal karena pasti akan mempengaruhi sama output kegiatan kita nanti." (Nelsy Ovalia, wawancara data primer, 11 April 2017) Pada pernyataan diatas menjelaskan bahwa 
pentingnya komunikasi internal pada Hotel Grand Sahid Jaya - Jakarta, apalagi ditambah penyelenggaraan suatu acara di hotel tidak mungkin hanya dihandle dari satu departemen saja, melainkan tak luput dari dukungan departemen lain lah yang bisa memberikan dukungan sukses atau tidaknya suatu kegiatan di hotel tersebut Sebagai seorang project leader dari Event Sunrise Yoga from The Skyline, narasumber ketiga menyatakan bahwa selain menjaga komunikasi internal, juga sangat penting untuk membina hubungan baik pada komunikasi eksternal, yang pada penelitian ini yang dimaksud yakni tamu hotel atau peserta Event Sunrise Yoga from The Skyline yang menyatakan "Harus pinter mingle, mulai dari via whatsapp, sampe pas ketemu sebelom acara, dan abis acara harus seasik mungkin sama peserta jadi ngga kaku cara komunikasinya. Abis acara yoga kita lanjut duduk dan breakfast bareng sambil ngobrol ngobrol, nah disitu kita mulai pitching buat ngobrolin next event yoga kita, kita kadang juga bantu mereka buat yang mau foto di helipad kita karena mereka bilang view disana bagus banget." (Nelsy Ovalia, wawancara data primer, 11 April 2017)

Pernyataan diatas dari Nelsy Ovalia mendeskripsikan seberapa pentingnya dalam berkomunikasi dengan pihak eksternal yang yakni adalah tamu hotel dari Hotel Grand Sahid Jaya - Jakarta, bahkan tak jarang banyak tamu baru yang datang dari hasil foto instagram yang diunggah dari peserta lama Event Sunrise Yoga from The Skyline.

\section{Back Up Management}

Alat pendukung dalam adanya fungsi manajemen organisasi atau suatu perusahaan. (Ruslan, 2005, p.10) "Sebagai bagian dari public relations, dukungan yang sudah dilakukan adalah kita mengoptimalkan seluruh cara komunikasi agar dapat mempermudah publik dalam mengakses media sosial kita, kita juga selalu buat konsep visual sehingga lebih instagrammable dan lebih mudah untuk dipahami masyarakat dan ngga bosenin." (Idham Yassin, wawancara data primer, 11 April 2017)

Bentuk dukungan yang diberikan public relations yakni diantaranya yang terpenting adalah untuk mempermudah publik mendapatkan informasi yang mereka inginkan mengenai Hotel Grand Sahid Jaya - Jakarta, tak hanya itu divisi public relations juga terus berusaha untuk mengoreksi usaha yang dilakukan demi mengoptimalisasi hasil kerja mereka pada pernyataan berikut . "Kelebihannya karena media sosial bersifat cepat dan bisa diakses dalam bersamaan dengan penggunaan media sosial lainnya, kekurangannya ya kurang bisa digunakan buat menjalin komunikasi interpersonal jadi kurang dapet feelnya dibanding yang face to face meeting." (Idham Yassin, wawancara data primer, 11 April 2017). Memiliki peran dalam public relations yakni juga harus terus berupaya untuk menganalisa kekurangan dan kelebihan dalam teknik yang digunakan, hal ini berguna untuk mengoptimalisasi teknik yang dapat bekerja secara efektif dan meminimalisir dan mengganti teknik-teknik yang kiranya tidak bekerja secara efektif seperti yang dinyatakan oleh narasumber kedua yakni "Semoga kedepannya kita bisa nemuin cara atau media yang bisa memaksimalkan pesan yang terkirim dari kita dengan berkembangnya teknologi. Ngga menutup kemungkinan buat ganti media sosial yang lebih transparan dan cepat, jadi semakin gampang buat diakses public." (Idham Yassin, wawancara data primer, 11 April 2017)

\section{Corporate Image}

Peranan public relations berupaya menciptakan citra bagi perusahaan atau lembaganya yang bersangkutan. (Ruslan, 2005, p.10) "Ya, riset dibuat dan ditujukan kepada para peserta yang mengikuti yoga dan para media yang datang meliput kegiatan yoga, hasil riset tersebut menyatakan bahwa Hotel Grand Sahid Jaya saat ini lebih aktif dan kreatif dalam mengadakan acara-acara terutama acara yang berkaitan dengan gaya hidup sehat seperti yoga di helipad tsb." (Yuanita Ayu Pratama, wawancara data primer, 11 April 2017). 
Adanya perubahan citra yang terbentuk setelah diadakannya Event Sunrise Yoga from The Skyline, perubahan citra dari Hotel Grand Sahid Jaya - Jakarta ini tak lain dan tak bukan karena tingkat kepedulian hotel dalam isu kesehatan yakni mengadakan acara sesi yoga yang sebelumnya belum pernah diadakan di hotel ini. Tak hanya itu, narasumber pertama juga menyatakan citra yang terbentuk sebelum diadakannya kegiatan ini adalah hanya hotel yang ditujukan untuk keperluan bisnis dan rapat pemerintahan saja, seperti yang ia nyatakan berikut "Citra hotel sebelum diadakannya event ini adalah hotel yang hanya mengakomodir keperluan bisnis dan meeting delegasi pemerintahan di Jakarta." (Yuanita Ayu Pratama, wawancara data primer, 11 April 2017).

Hal ini juga satu suara dengan pernyataan narasumber keempat yang merupakan peserta dari Event Sunrise Yoga from The Skyline, ia sudah mengikuti kegiatan ini selama 3 pertemuan, ia menyatakan :"Saya pikir awalnya hotel ini cuman buat hotel meeting karena ngga terlalu banyak temen-temen saya yang dateng kesini buat weekend-an biasanya pada kesini buat rapat atau pertemuan doang, tapi ternyata hotel ini malah yang bikin acara yoga yang lebih kerennya diadain di helipad, dan belom pernah diadain di hotel lain yang punya helipad, jadi keren sih dan harganya juga terjangkau banget buat kita" (Maya Puspita Dewi, wawancara data primer, 25 April 2017) Pada pernyataan diatas, menunjukan bahwa adanya persamaan persepsi yang ingin diciptakan oleh pihak internal yakni divisi public relations dan pihak eksternal yakni tamu hotel yang dalam penelitian ini adalah peserta Event Sunrise Yoga from The Skyline.

Berdasarkan hasil analisa yang didapat mengenai peran public relations yang dilakukan oleh divisi public relations dari Hotel Grand Sahid Jaya - Jakarta, peneliti sudah melakukan analisa keempat narasumber yang memiliki pengalaman dan informasi yang berkaitan dengan Hotel Grand Sahid Jaya dan Event Sunrise Yoga from The Skyline menunjukan bahwa secara intensif mengubah citra publik eksternal dari citra awal Hotel Grand Sahid Jaya - Jakarta, yakni hotel yang hanya ditujukan untuk kebutuhan bisnis dan rapat pemerintahan yang secara pelan pelan berubah menjadi hotel yang aktif dan kreatif dalam mengadakan acara yang berkaitan dengan gaya hidup sehat atau yang ada kaitannya dengan kesehatan. Hal ini menunjukan bahwa implementasi dari event ini sangat langsung berdampak dengan citra yang terbentuk secara perlahan dari Hotel Grand Sahid Jaya Jakarta.

Berdasarkan model pembentukan citra yang berbentuk kerangka konseptual, yang disusun untuk melihat bagaimana cara proses pembentukan citra dengan menggunakan pendekatan Model Pembentukan Citra yang dijelaskan oleh Nimpoeno dalam struktur kognitif, dalam laporan penelitian tentang Tingkah Laku Konsumen yang dikutip Danasaputra sebagai berikut :

\section{Persepsi}

Langkah yang dilakukan oleh Hotel Grand Sahid Jaya - Jakarta dalam meningkatkan citranya yakni adalah menyelenggarakan acara Sunrise Yoga from The Skyline, acara yoga ini adalah acara yang awalnya dibuat untuk tahunan namun karena demand dari publik yang sangat banyak, manajemen memutuskan untuk menjadikan kegiatan ini menjadi kegiatan bulanan dari Hotel Grand Sahid Jaya - Jakarta, acara ini dibuat antara lain adalah untuk memanfaatkan fasilitas helipad yang tersedia di hotel, yang kedua adalah untuk merangkul komunitas yang peduli dengan isu kesehatan maupun gaya hidup sehat.

\section{Kognisi}

Public Relations Hotel Grand Sahid Jaya - Jakarta senantiasa menjaga dan membina hubungan yang harmonis dengan media dalam penyebaran media informasi, dan juga selalu rutin dalam menyebarkan informasi kegiatan Sunrise Yoga from The Skyline dari media sosialnya, sehingga mempermudah publik untuk mendapatkan informasi mengenai 
kegiatan ini. Adanya media eksternal yang sudah mempublikasikan hasil kegiatan Sunrise Yoga from The Skyline adalah CNN Indonesia, Media Indonesia, Xin Hua News, Reuters London, Tribunnews.com, Jawa Pos, dll. Sedangkan media sosial milik Hotel Grand Sahid Jaya yang digunakan untuk mengunduh post berisi informasi dari kegiatan ini adalah berupa; facebook, twitter, instagram, youtube.

3. Motivasi

Sebagai motivasi antar karyawan, public relations senantiasa bekerja sama dengan Human Resources Department dalam memotivasi karyawannya untuk terus mengoptimalisasi pelayanan terhadap tamu hotel yang saat dalam penelitian ini adalah peserta Sunrise Yoga from The Skyline, tak luput dari visi dan misi yang selalu diindahkan untuk terus memompa semangat para karyawan dalam bekerja. Di satu sisi dari bagian eskternal, banyak sekali peserta yoga yang termotivasi untuk ikut kegiatan ini karena mereka sangat senang dengan tempat yoga diadakan dimana di helipad, belum ada sebelumnya kegiatan yoga yang diadakan di helipad sebelum diselenggarakan oleh Grand Sahid Jaya Jakarta.

4. Sikap

Sikap merupakan faktor vital dalam pembentukan suatu citra perusahaan, pada akhirnya sikap yang akan menjadi acuan perusahaan mengenai pro atau kontranya segala bentuk kegiatan atau stategi yang diadakan di Hotel Grand Sahid Jaya, maka dengan meluncurkan program Sunrise Yoga from The Skyline, mereka selalu memberikan konsistensi dalam pelayanan terbaik untuk selalu melayani tamu hotel yang menikmati layanan Hotel Grand Sahid Jaya - Jakarta, karena sesungguhnya pada saat banyak tamu itulah menjadi kesempatan mereka untuk unjuk gigi kualitas bintang lima hotel yang mereka miliki, apabila mujur dan tamu merasa puas dengan pelayanan tidak menutup kesempatan itu menjadi pintu emas untuk menjemput tamu hotel baru yang tidak pernah ke Hotel Grand Sahid Jaya - Jakarta sebelumnya.

\section{PENUTUP}

Dalam melakukan peran sebagai Public Relations dari institusi tertentu, dibutuhkan beberapa upaya yang harus dilakukan guna mencapai tujuan yang diharapkan. Penelitian ini berfokus pada peran Public Relations dari divisi public relations Hotel Grand Sahid Jaya Jakarta. Mengacu pada empat peran Public Relations menurut Rosady Ruslan, terdapat satu peran yang peneliti rasa belum dapat dikerjakan secara maksimal yakni Back $U p$ Management, dimana divisi public relations masih kesulitan untuk menemukan media yang tepat dalam menjangkau publik secara personal, padahal kita tahu bahwa itu merupakan hal penting dalam mencapai public engagement yang sangat dibutuhkan oleh Hotel Grand Sahid Jaya - Jakarta. Peneliti memberikan saran agar selalu berinovasi terhadap perkembangan teknologi yang dapat memudahkan hotel untuk menjangkau publik, tidak hanya secara media sosial online saja tapi juga secara personal, maka dari itu seluruh divisi public relations harus tetap membuka kesempatan selebar-lebarnya untuk improvisasi dalam sistem komunikasi antar eksternal.

\section{REFERENSI}

Akil, M. (2013). Fungsi dan Peran Corporate Communications Dalam Meningkatkan Citra Perusahaan. PT Garuda Indonesia (Persero), Tbk. Universitas Hasanudin.

Ardianto, E. (2009) Metodologi Penelitian Untuk Public Relations: Kuantitatif dan Kualitatif. Bandung: Simbiosa Rekatama Media. 
Axa. (2016) Kenali Jenis Yoga Yang Sesuai Dengan Anda. Diakses pada 20 November 2016. Diperoleh dari website axa.co.id: https://axa.co.id/inspirasi/kenali-jenis-yogayang-sesuai-dengan-anda/

Cutlip, Center, \& Broom. (2006) Effective Public Relations. Jakarta: Kencana.

Effendy. (2006) Hubungan Masyarakat suatu Komunikologis. Bandung. Remaja Rosdakarya.

Dwiyantari. (2016) Filosofi Yoga. Diakses pada 16 November 2016. Diperoleh dari website dwiyantariyoga.wordpress: https://dwiyantariyoga.wordpress.com/2013/09/23/filosofiyogal

Herawan. (2016) Okupansi Hotel Turun Di Jakarta Penyebabnya. Diakses 14 November 2016. Diperoleh dari rumah.com: http://www.rumah.com/beritaproperti/2016/4/123286/okupansi-hotel-di-jakarta-turunini-penyebabnya

Hotel Grand Sahid Jaya - Jakarta. (2016), Company Profile Hotel Grand Sahid Jaya _ Jakarta.

Mulyana, D. (2011) Ilmu Komunikasi Suatu Pengantar. Bandung: PT Remaja Rosdakarya.

Nova, F. (2009) Crisis Public Relations: Bagaimana PR Menangani Krisis Perusahaan. Jakarta: Grasindo.

Nurjaman, K. U. (2012) Komunikasi \& Public Relations. Bandung: Pustaka Setia.

Perempuan.com (2016) Generasi O Generasi Masa Kini Yang Makin Jauh dari Pola Hidup Sehat. Diakses 15 November 2016. Diperoleh dari website perempuan.com: http://perempuan.com/health/generasi-o-generasi-masa-kini-yang-makin-jauh-daripola-hidup-sehat/

Permando. (2015) Hasil Survei Kesadaran Hidup Sehat Masyarakat Meningkat. Diakses pada 20 November 2016. Diperoleh dari website lifestyle.bisnis:http://lifestyle.bisnis.com/read/20151113/220/491709/hasil-surveikesadaran-hidup-sehat-masyarakat-meningkat

Rey. (2016) Pengantar Teori Generasi Strauss-Howe. Diakses pada 21 Oktober 2017. Diperoleh dari website https://reysatrio.wordpress.com/2016/02/09/pengantar-teorigenerasi-strauss-howe-2/

Rumah.com. (2016) Okupansi Hotel Turun Di Jakarta Penyebabnya. Diakses 14 November 2016.Diperoleh dari rumah.com: http://www.rumah.com/beritaproperti/2016/4/123286/okupansi-hotel-di-jakarta-turunini-penyebabnya

Rumanti A. (2002) Dasar - Dasar Public Relations: Teori dan Praktik: Jakarta: Grasindo.

Ruslan, R. (2003) Metode Penelitian Public Relations dan Komunikasi. Jakarta: PT Raja Grafindo Perkasa.

Ruslan, R. (2010) Manajemen Public Relations dan Media Komunikasi: Konsepsi dan Aplikasi. Jakarta: PT Raja Grafindo Persada.

Soemirat, Soleh \& Elvinaro, A. (2012) Dasar - dasar Public Relations. Bandung: PT Remaja Rosdakarya.

Sugiyono. (2005) Memahami Penelitian Kualitatif. Bandung: Alfabeta

--------, (2011) Metode Penelitian Kuantitatif Kualitatif R\&D. Bandung: Alfabeta.

Susanti, E. (2014) Strategi Public Relations Dalam Meningkatkan Citra Organisasi. Sarjana Ekonomi, Universitas Negeri Surabaya.

Tondowidjojo, John. (2004.) Dasar dan Arah Public Relations. Jakarta: PT Grasindo. , (2003), Intisari Ajaran Agama Hindu. Diakses 16 November 2016. Diperoleh dari hinduisme.blogspot: http://dear-hinduisme.blogspot.co.id/2012/11/agama-hindusad-darsana-ii.html. 